\title{
Histological Analysis of Early Gonadal Development and Sex Differentiation in Chameleon Goby, Tridentiger trigonocephalus
}

\author{
Hyun Chul Cho ${ }^{1}$, In Joon Hwang ${ }^{2}$, and ${ }^{\dagger}$ Hea Ja Baek ${ }^{1}$ \\ ${ }^{1}$ Department of Marine Biology, Pukyong National University, Busan 608-737, Republic of Korea \\ ${ }^{2}$ Genetics and Breeding Research Center, National Fisheries Research and Development Institute, \\ Geoje 656-842, Republic of Korea
}

\begin{abstract}
This study describes the developmental process of gonads in chameleon goby, Tridentiger trigonocephalus from the stage of hatching to 100 days after hatching (DAH). Based on histological observation, the primordial germ cells were observed in mesentery between mesonephric duct and gut at $15 \mathrm{DAH}$ (total length, TL: 6.8 $\pm 0.2 \mathrm{~mm}$ ). At $20 \mathrm{DAH}$ (TL: $7.9 \pm 0.1 \mathrm{~mm}$ ), the primordial gonad began to protrude into peritoneal cavity and developed between mesonephric duct and gut. Initial ovarian differentiation was identified by the presence of ovarian cavity and oogonia in the gonads at 55 DAH (TL: $21.1 \pm 1.3 \mathrm{~mm}$ ). Testicular differentiation started at $65 \mathrm{DAH}$ (TL: $23.7 \pm 0.9 \mathrm{~mm}$ ) with appearance of spermatogonial cells in the gonads. These findings indicate that sex differentiation in T. trigonocephalus occurs earlier in females than males, suggesting that this species can be classified as an undifferentiated gonochorist.
\end{abstract}

Key words: Chameleon goby, Early gonadal development, Sex differentiation, Histology

\section{INTRODUCTION}

In teleost, the developmental patterns leading to the expression of gonadal sex are controlled by genetic, environmental and social factors. Different patterns of gonadal development have been described, including gonochoristic and hermaphroditic species (Nagahama et al., 1998; Devlin \& Nagahama, 2002; Guerrero-Estevez \& Moreno-Mendoza, 2010). Gonochoristic species may be differentiated or undifferentiated. In the differentiated gonochoristic species, early gonad development proceeds from an indifferent gonad directly to ovary or testis (Piferrer \& Donaldson, 1989; Lee et al., 1996); in the undifferentiated species, all individuals develop an initial gonad similar to an ovary, which subsequently differentiated into a testis in approximately half of the population, and into a proper ovary in the other half (Guerrero-Estevez \& Moreno-Mendoza, 2010). Some gonochoristic species go through a period where all gonads are initially intersexual prior to differentiation into either testis or ovary (Sadovy \& Colin, 1995; Asoh \& Shapiro, 1997).

The gobies, mostly small are one of the largest families in the Perciformes. They are distributed worldwide, in marine, estuarine and freshwater habitats (Nelson, 1984). Many of the gobiid fish have one or two years total lifespan. Recently, the external environmental changes and

\footnotetext{
Manuscript received 8 January 2014, Received in revised form 3 February 2014, Accepted 5 February 2014

${ }^{\dagger}$ Corresponding Author : Hea Ja Baek, Department of Marine Biology, Pukyong National University, Busan 608-737, Republic of Korea. Tel : +82-51629-5924, Fax : +82-51-629-5931, E-mail : hjbaek@pknu.ac.kr

This is an Open Access article distributed under the terms of the Creative Commons Attribution Non-Commercial License (http:// creativecommons.org/licenses/by-nc/3.0) which permits unrestricted non-commercial use, distribution, and reproduction in any medium, provided the original work is properly cited.
} 
contaminants' influencing the gobiid fish have been studied intensively (Baek et al., 2004, 2007; Mochida et al., 2004; Ito et al., 2007; Robinson et al., 2007; Saaristo et al., 2009). However, little is known about early gonad development in fishes in general, and gobies in particular. Gobiid fish exhibit a variety of sexual patterns including gonochorism, simultaneous hermaphroditism and protogyny (Cole, 1990).

The chameleon goby, Tridentiger trigonocephalus, is in the genus Tridentiger of the family Gobiidae. Their habitats extend from China, Japan, Russia, to the northwest region of the USA, and include the mudflats in the southern and western coastal waters, brackish and freshwater in South Korea (Chung, 1977). In the previous study, we investigated the reproductive cycle of chameleon goby (Hwang \& Baek, 2013). The aim of this study was to describe early gonadal development and determine the timing of gonadal differentiation using the histological method.

\section{MATERIALS AND MATHODS}

\section{Fish}

The experimental fish were collected in the eelgrass bed around Dongdae Bay, Namhae, Gyeongsangnamdo, South Korea using a scoop net. Male and female were maintained under a photoperiod of $14 \mathrm{~h}$-light and $10 \mathrm{~h}$-dark at $21 \pm 0.5^{\circ} \mathrm{C}$ in $90 \mathrm{~L}$ indoor aquarium system. Polyvinyl-coated (PVC) pipes (5 $\mathrm{cm}$ in diameter and $12 \mathrm{~cm}$ long) were used as spawning substrates. Substrates containing eggs were collected from the brood stock aquaria and were placed in a $30 \mathrm{~L}$ glass aquaria. As soon as the hatching completes, substrates were removed from aquaria. Larvae were fed with rotifer, Brachionus rotundiformis alone for 15 days after hatching (DAH), rotifer and brine shrimp, Artemia nauplii for the next 5 days, and brine shrimp for the next 10 days. Fish older than $30 \mathrm{DAH}$ were fed with artificial feed until the end of the experiment.

\section{Sampling schedule}

Larvae samples (from 1 to $100 \mathrm{DAH}$ ) were collected for the gonadal histological study. Its samples (5 fish) were collected every 3 days between day 1 to 15 , every 5 days between day 15 to 70 , and every 10 days between day 70 to 100 .

\section{Histological observation of sex differentiation}

For the histological observation, larvae and juveniles were fixed in Bouin's solution for 24 hours and then embedded in paraffin. The paraffin embedded specimens were sectioned in 5 to $6 \mu \mathrm{m}$ thick sections. The sections were stained with Mayer's hematoxylin-eosin, and observed under a light microscope (BX 50, Olympus, Japan).

\section{RESULTS}

\section{Growth of larvae and juvenile}

During experimental period (from 3 to $100 \mathrm{DAH}$ ), total length of chameleon goby larvae and juveniles ranged from 2.6 to $38.8 \mathrm{~mm}$ respectively. Growth curve in total length related to DAH was estimated by the Gompertz growth curve. The growth curve of chameleon goby larvae and juvenile could be expressed as :

$$
T L=158.25 \cdot e^{-\epsilon\left(-\frac{t-25.57}{17.50}\right)}
$$

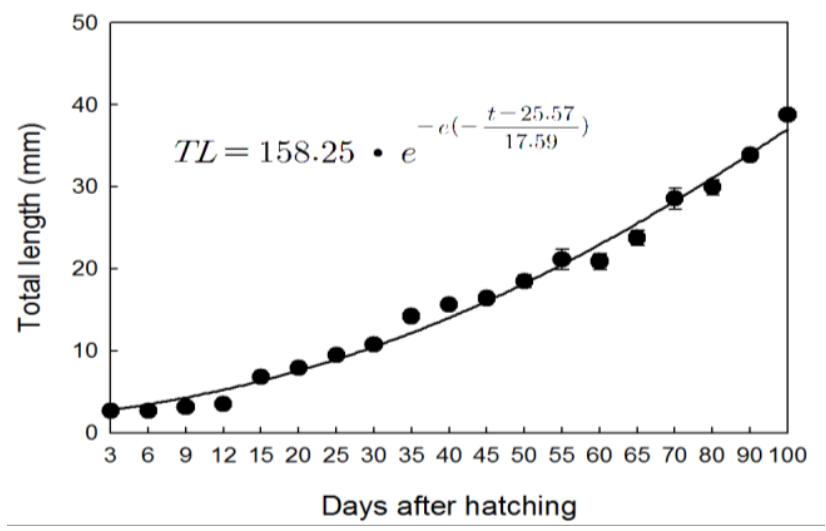

Fig. 1. Growth in total length of chameleon goby larvae and juveniles. Values are mean \pm S.E. $(n=5)$. 


\section{Gonadal differentiation and development}

\section{1) Undifferentiated gonad phase}

The primordial germ cell (PGC) was observed in mesentery between mesonephric duct and gut at $15 \mathrm{DAH}$ (total length, TL: $6.8 \pm 0.2 \mathrm{~mm}$ ). At this stage, PGCs with large nuclei which were intensively stained by hematoxylin were located in the germinal epithelium line adjacent hindgut.

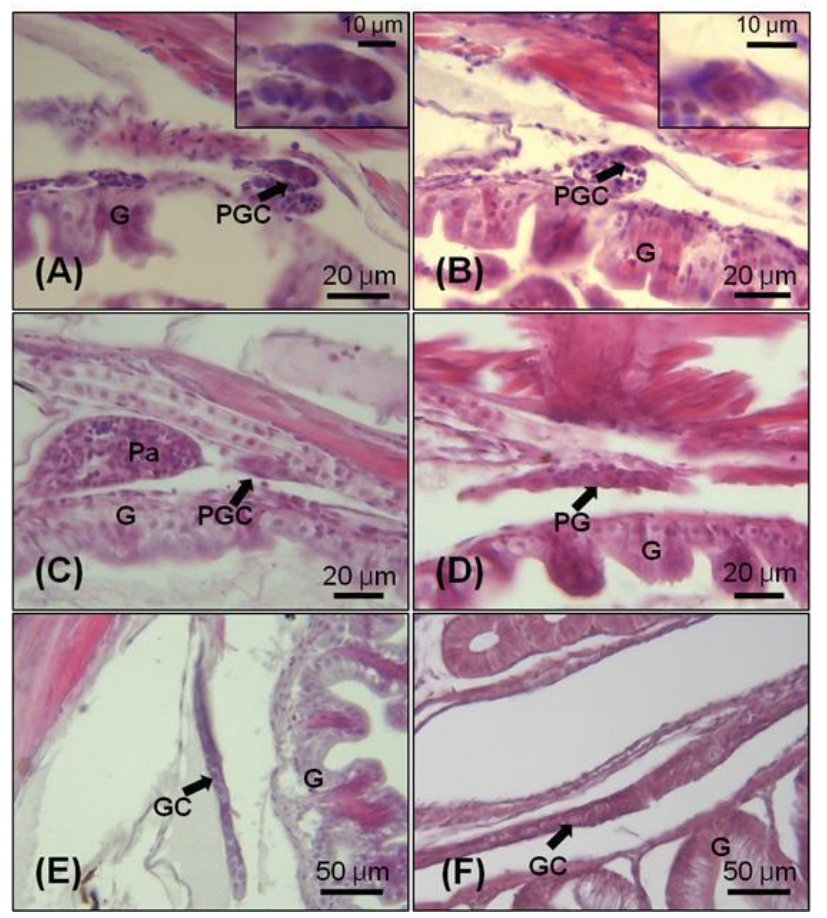

Fig. 2. Gonadal differentiation in Tridentiger trigonocephalus at varying days post hatching. (A) and (B); Undifferentiated gonad of 15 days post hatching postlarva. Primordial germ cells were observed near the mesonephric duct. (C) and (D); Undifferentiated gonad of 20 days post hatching postlarva. Primordial gonad was observed with a few somatic cell below mesonephric duct. (E); Undifferentiated gonad of 30 days post hatching postlarvae. Primordial gonad was observed with germ cells surrounded by somatic cells. (F); Undifferentiated gonad of 45 days post hatching juvenile. The number of germ cells and somatic cells increased by mitosis of the cells. $\mathrm{G}$, gut; Gc, germ cell; Pa, pancreatic; PG, primordial gonad; PGC, primordial germ cell.
The diameter of PGCs ranged from 10 to $12 \mu \mathrm{m}$ (Fig. 2-A, B). At 20 DAH (TL: $7.9 \pm 0.1 \mathrm{~mm}$ ), the primordial gonad with a few somatic cell developed and began to protrude into the peritoneal cavity between mesonephric duct and gut (Fig. 2-C, D). At the 30 DAH (TL: $10.7 \pm 0.3 \mathrm{~mm}$ ), the germ cells were surrounded by somatic cells and distinguished from the somatic cells by their larger size. Nuclei of the germ cells were stained by hematoxylin more intensively than cytoplasm (Fig. 2-E). At 45 DAH (TL: $15.6 \pm 0.3 \mathrm{~mm}$ ), the primordial gonads were elongated and the number of germ cells and somatic cells increased by mitosis of the cells (Fig. 2-F).

\section{2) Ovarian differentiation phase}

Initial ovarian differentiation was identified by the presence of ovarian cavity and transformation of PGCs to meiotic oocytes. The oogonia were first observed in the gonads at 55 DAH (TL: $21.1 \pm 1.3 \mathrm{~mm}$ ), which indicate that oogenesis already initiated within the gonad. The oogonia at this stage were increased in number and diameter range from 20.0 to $35 \mu \mathrm{m}$ (Fig. 3-A). In 70 days juvenile (TL: $28.6 \pm 1.3$

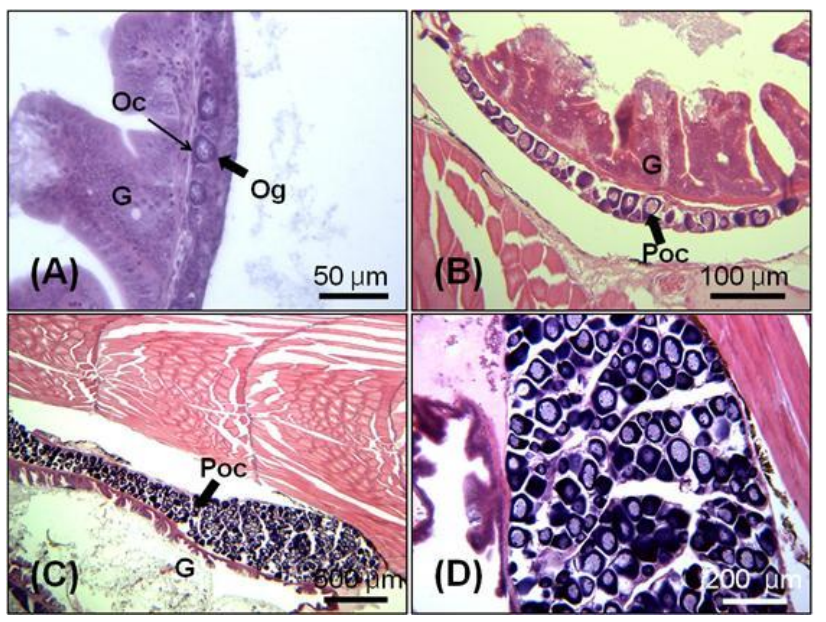

Fig. 3. Ovarian differentiation in Tridentiger trigonocephalus at varying days post hatching. (A); Differentiated ovary of 55 days post hatching; (B); Ovary with perinucleolus oocytes of 70 days post hatching. (C) and (D); Ovary with 100 DAH. G, gut; Oc, ovarian cavity; Og, oogonia; Poc, perinucleolus oocytes. 
$\mathrm{mm}$ ), the ovary started to fill with perinucleolus oocytes (Fig. 3 -B). At the $100 \mathrm{DAH}$ (TL: $38.8 \pm 0.5 \mathrm{~mm}$ ), the gonad was rapidly increased in size compared with those at $70 \mathrm{DAH}$ (Fig. 3-C, D).

\section{3) Testicular differentiation phase}

At 65 DAH (TL: $23.7 \pm 0.9 \mathrm{~mm}$ ), the testicular differentiation was identified by the presence of spermatogonial cells (Fig. 4-A). In 70 days juvenile (TL: $28.6 \pm 1.3 \mathrm{~mm}$ ), the testis became bigger and the number of spermatogonia started to increase (Fig 4-B). Seminiferous tubules of testis were filled with numerous spermatogonia in 90 days juvenile (TL: $33.8 \pm 0.5$ mm, Fig. 4-C, D).

\section{DISCUSSIONS}

Most teleost species are gonochoristic, i.e., individuals develop only as males or females and remain go through-out their life span (Yamamoto, 1969). Sex differentiation has been shown to begin first in the gonads of females than in males in the majority of the gonochoristic teleosts examined to date.

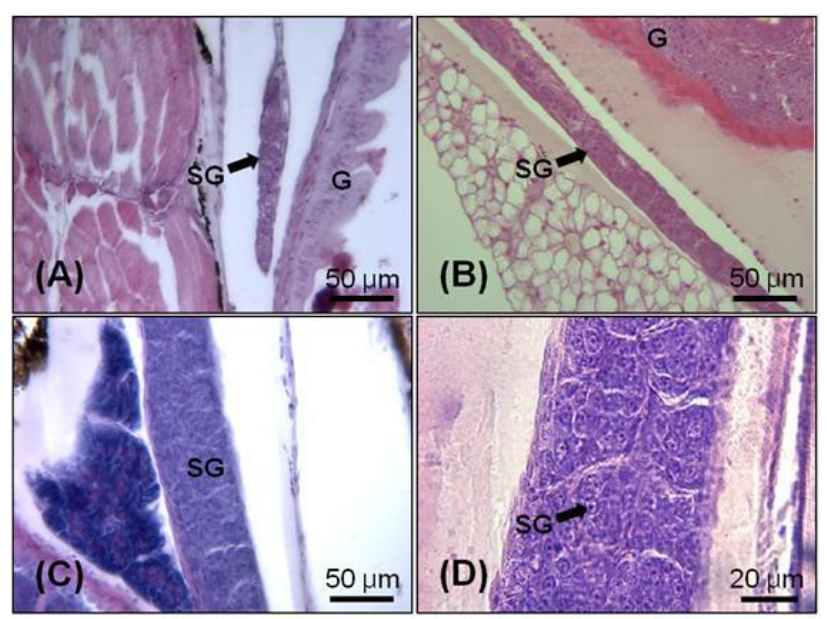

Fig. 4. Testicular differentiation in Tridentiger trigonocephalus at varying days post hatching. (A); Differentiated testis of 65 days post hatching. (B); Differetiated testis of 70 days post hatching. (C) and (D); Testis with spermatogonia of 90 days post hatching. G, gut; SG, spermatogonia.
However, the initial pathway of gonadal development may vary. Some species may develop gonads which are initially hermaphroditic, but later develop as ovaries or testicles (Devlin \& Nagahama, 2002).

Results from this study show differentiation of ovarian tissue has been observed 55 days post hatching, whereas differentiation of testicular tissue occurs about 10-15 days later; germ cells mitosis in females and males were first observed at 55 and 65-70 days after hatching, respectively. Testicular development usually occurs later than ovarian differentiation, some weeks or months after the onset of gonad development in females of some species (Guraya, 1994; Nakamura et al., 1998). In some species spermatogenesis begins long after hatching, in $O$. mossambicusand $O$. niloticus, spermatogenesis starts 50-70 days after hatching (Nakamura \& Nagahama, 1989), and in medaka, 50 days after hatching (Matsuda, 2005). In the medaka, the female germ cells become differentiated much earlier than do male germ cells (Saito et al., 2007).

The processes of sexual differentiation in fish are highly plastic. Several species among the gobiids are protogynus hermaphrodites, such as the bluebanded goby (Lythrypnus dalli). This is predominantly a protogynus fish (Cole, 1990; Reavis \& Grober, 1999) but is capable of bi-directional sex change (Reavis \& Grober, 1999; Kroon et al., 2003; Rodgers et al., 2007).

Based on histological observation, the chameleon goby exhibit undifferentiated gonochorism where the undifferentiated gonad develops an initial gonad similar to an ovary, which subsequently differentiated into a testis, and this species can be classified as an undifferentiated gonochorist. However, at this time, histological evidence does not reveal distinction of female or male gonadal cell types.

\section{ACKNOWLEDGEMENT}

This work was supported by a Research Grant of Pukyong National University (C-D-2011-0849), Korea. 


\section{REFERENCES}

Asoh K, Shapiro DY (1997) Bisexual juvenile gonad and gonochorism in the fairy basslet, Grammaloreto. Copeia 1997: 22-31.

Baek GW, Kim JW, Huh SH (2004) Maturation and spawning of striped goby, Acentrogobius pflaumi collected in the Gwangyang Bay, Korea. J Kor Fish Soc 37:226-231.

Baek HJ, Hwang IJ, Kim KS, Lee YD, Kim HB, Yoo MS(2007) Effects of BPA and DES on longchin goby, Chasmichthys dolichognathus in vitro during oocyte maturation. Mar Environ Res 64:79-86.

Chung (1977) The Fishes of Korea. Inji-sa, Seoul, pp 727.

Cole (1990) Patterns of gonad structure in hermaphroditic gobies

(Teleostei Gobiidae). Environmental Biology of Fishes 28: 125-142.

Delvin RH, Nagahama Y(2002) Sex determination and sex differentiation in fish: an overview of genetic, physiological, and environmental influences. Aquaculture 208:191-364.

Guerrero-Estevez, Moreno-Mendoza (2010) Sexual determination and differentiation in teleost fish. Rev Fish Biol Fisheries 20:101-121.

Guraya SS (1994) Gonadal development and production of gametes in fish. Proc Indian Natl Sci Acad Part B 60:15-32.

Hwang IJ, Baek HJ (2013) Reproductive cycle of Chameleon goby, Tridentiger trigonocephalus in the southern coastal waters of Korea. Dev Reprod 17:353-361.

Ito K, Mochida K, Fujii K (2007) Molecular cloning of two estrogen receptors expressed in the testis of the Japanese common goby, Acanthogobius flavimanus. Zool Sci 24:986-996.

Kroon FJ, Munday PL, Pankhurst NW (2003) Steroid hormone levels and bi-directional sex change in Gobiodon histrio. Journal of Fish Biology 62: 153-167.

Lee YD, Rho S, Chang YJ, Baek HJ, An CM (1996) Sex differentiation of the Rockfish, Sebastes schlegeli. Bull
Kor Fish Soc 29:44-50.

Matsuda M (2005) Sex determination in the teleost medaka, Oryzias latipes. Annu Rev Genet 39:293-307.

Mochida K, Ohkubo N, Matsubara T, Ito K, Kakuno A, Fujii K (2004) Effects of endocrine-disrupting chemicals on expression of ubiquitin C-terminal hydrolase mRNA in testis and brain of the Japanese common goby. Aquat Toxicol 70:123-136.

Nakamura M, Kobayashi T, Chang XT, Nagahama Y (1998) Gonadal sex differentiation in teleost fish. J Exp Zool 281:362-372.

Nakamura M, Nagahama Y (1989) Differentiation and development of Leydig cells and change of testosterone levels during testicular differentiation in tilapia Oreochromis niloticus. Fish Physiol Biochem 7:211219.

Nelson JS (1984) Fishes of the World. 2nd ed. John Wiley and Sons, New York, 523 pp.

Piferrer F, Donaldson EM (1989) Gonadal differentiation in coho salmon, Oncorhynchus kisutch, after a single treatment with androgen or estrogen at different stages during ontogenesis. Aquaculture 77:2-3.

Reavis R, Grober MS (1999) An integrative approach to sex change: Social, behavioural and neurochemical changes in Lythrypnus dalli. Acta Ethologica 2:51-60.

Robinson CD, Brown E, John A, Craft, Davies IM, Megginson C, Miller C, Moffat CF (2007) Bioindicators and reproductive effects of prolonged $17 \beta$-oestradiol exposure in a marine fish, the sand goby, Pomatoschistus minutus. Aqua Toxicol 81:397-408.

Rodgers EW, Earley RL, Grober MS (2007) Social status determines sexual phenotype in the bidirectional sex changing bluebanded goby (Lythrypnus dalli). Journal of Fish Biology 70:1660-1668.

Saaristo M, Craft JA, Lehtonen KK, Björk K, Lindström K (2009) Disruption of sexual selection in sand gobies (Pomatoschistus minutus) by $17 \alpha$-ethinyl estradiol, an endocrine disruptor. Horm Behav 55:530-537. 
HC Cho, IJ Hwang, HJ Baek

Sadovy Y, Colin PL (1995) Sexual development and sexuality in the Nassau grouper. J Fish Biol 46:961-976.

Saito D, Morinaga C, Aoki Y, Nakamura S, Mitani H, Furutani-Seiki M, Kondoh H, Tanaka M (2007) Proliferation of germ cells during gonadal sex differ- rentiation in medaka: insights from germ cell-depleted mutant zenzai. Dev Biol 310:280-290.

Yamamoto T (1969) Sex differentiation. In: Hoar WS \& Randall DJ (ed.), Fish Physiology Vol III, Academic Press, New York, pp 117-175. 